\title{
Fungi open new possibilities for anaerobic fermentation of organic residues
}

\author{
Marian Kazda ${ }^{1 *}$, Susanne Langer $^{2}$ and Frank R Bengelsdorf ${ }^{2}$
}

\begin{abstract}
Background: Large amounts of fibre-rich organic waste material from public green and private gardens have to be treated environmentally friendly; however, this fibre-rich biomass has low biogas yields. This study investigated the presence of fungi in full-scale biogas plants as well as in laboratory reactors and elucidated the importance of fungi for the biogas process.

Methods: The dominating members of the eukaryotic community were identified by analyzing 18S rRNA gene and internal transcribed spacer 1 (ITS1) region fragments of clone libraries. These identifications were accompanied by diverse microscopic techniques such as fluorescence microscopy and conventional scanning electron microscopy.

Results: Cells of presumably fungal origin were characterized by intensive fluorescence and were about 1 order of magnitude larger than prokaryotic cells. Molecular techniques enabled to identify fungi from the subphyla Agaricomycotina, Mucoromycotina, Pezizomycotina, Pucciniomycotina and Saccharomycotina and from the class Neocallimastigomycetes. Members of these groups can be important for microbial degradation of complex compounds, due to the ability to penetrate cell walls, and thus open the cells for the influx of bacteria, further enhancing degradation.

Conclusions: Optimal treatment of biowaste depends on the amount of lignocelluloses. Targeted application of fungi to the biogas process will open wider possibilities for anaerobic treatment of fibre-rich biomass and can result in better biomass utilization as a renewable energy resource. Due to higher temperature optima of fungal cellulolytic enzymes, the thermophilic process is suggested for anaerobic degradation of fibre-rich biomass.
\end{abstract}

Keywords: Biogas; Biowaste treatment; Fibre-rich biomass; Fungal ITS1 sequences; Lignocelluloses

\section{Background}

Energy crops and organic residues can serve as substrates for anaerobic digestion with further utilization of the obtained methane as a source of sustainable energy [1]. Amounts of municipal solid waste (MSW) as well as of organic waste are closely correlated to gross domestic product (GDP) and are therefore increasing sharply in many countries [2]. Household waste is collected regularly in most countries at public expense and subsequently incinerated or landfilled [3]. In Germany, the organic fraction of MSW amounts up to $3.8 \mathrm{Mt} \mathrm{a}^{-1}$ and source sorting is implemented at $72 \%$ of the municipalities with a further increasing share. Another large source of organic waste material is urban gardening waste from public green and

\footnotetext{
* Correspondence: marian.kazda@uni-ulm.de

${ }^{1}$ Institute of Systematic Botany and Ecology, Ulm University,

Albert-Einstein-Allee 11, Ulm 89081, Germany

Full list of author information is available at the end of the article
}

private gardens. This amount is estimated to about 4 $\mathrm{Mt} \mathrm{a}^{-1}$ in Germany [4] and can also be utilized for energy generation. The advantage of biowaste over energy crops such as maize silage, sugar beet, etc. is the avoided competition between the substrate production for energy use and food production.

The anaerobic decomposition of organic compounds in the first steps of biogas production provides the basic substrates for the methanogens [5,6]. Aside from the known fermentative bacteria [7], microorganisms from the eukaryotic domain can also be involved in the fermentation processes. For instance, it is known that obligate anaerobic protozoa are part of the anaerobic ruminal microbiota [8-10]. The presence of episymbiotic methanogens in ruminal ciliated protozoa was already proven in the early 1980s [11]. Ten years later, Teunissen et al. [12] found that the most abundant fermentation products of

\section{实 Springer}

(C) 2014 Kazda et al.; licensee Springer. This is an open access article distributed under the terms of the Creative Commons Attribution License (http://creativecommons.org/licenses/by/2.0), which permits unrestricted use, distribution, and reproduction in any medium, provided the original work is properly cited. 
fungi in the anaerobic process are acetate, formate and hydrogen. Furthermore, anaerobic fungi are known to form co-cultures with ruminal methanogenic archaea which utilize the fungal hydrogen production [13]. The role of ruminal fungi in the degradation of plant fibres has been studied extensively $[9,10,14-17]$. The fungi can attach to the most lignified plant tissues [18] and are in turn followed by the ingress of cellulolytic bacteria which then gain access to the interior of otherwise less fermentable plant material. Fungal penetration therefore results in faster and more complete decomposition of fodder that enters the rumen [13]. Such fungal enhancement of decomposition could also be used in the biogas process; however, until recently, there is only limited knowledge about the occurrence of fungi in a biogas plant.

Most of the latest studies were focusing on the methanegenerating archaea (methanogens) $[7,14]$ which are the key microorganisms in the biogas-forming process [1]. The long-term stability of the whole microbial community of a mesophilic biogas plant supplied with pig slurry, sanitized food waste, stale bread and other residues was reported by Bengelsdorf et al. [19], who provided the first evidence of the continuous presence of fungi in a biogas reactor. In the current paper, we further refer to the eukaryotic fungal community members identified by different cultureindependent approaches using clone libraries, epifluorescence and conventional scanning electron microscopy (CSEM).

The presence of fungi in the biogas reactors was therefore put in the context of anaerobic treatment of not only fibre-rich materials such as gardening waste and municipal green waste but also agricultural residues such as straw. The current practice used in dealing with these substrates takes only scarcely the path of the anaerobic digestion, mostly because of limited degradability of fibrous substrates as well as technological problems such as floating layers in the most common wet digestion in completely stirred tank reactors. Then, biomass burning in incineration plants or composting are the most widespread treatments. Therefore, a brief analysis is provided for treatment approaches for different types of organic waste, analyzing their potential for regenerative energy generation under consideration of fungal fibrolytic potential.

\section{Methods}

\section{Specifications of the biogas plants and sampling}

Microbial communities were assessed in biogas plants located in southern Germany near Aulendorf (biogas plant 1, BP1) and Hermaringen (BP2) in Baden-Württemberg. BP1 utilizes predominantly sanitized food residues together with stale bread and occasionally also other substrates such as pig slurry, maize silage, potato peelings and grain husk. The biogas plant with an installed electric output of $380 \mathrm{kWh}$ consists of three mesophilic reactors with 350-, 450- and 1,200- $\mathrm{m}^{3}$ volume at a mean hydraulic residence time of 100 days. The investigated biogas reactor $\left(350 \mathrm{~m}^{3}\right)$ with a $\mathrm{pH}$ value of the slurry of $7.9 \mathrm{had}$ an organic loading rate of 3.5 to $4.0 \mathrm{~kg}$ volatile solids (VS) $\mathrm{m}^{-3}$ day $^{-1}$ with a total solid content of $4.5 \%$. The total solids contained on average $(n=14) 34 \%$ total carbon (C) and $4 \%$ total nitrogen $(\mathrm{N})$, giving a rather low $\mathrm{C} / \mathrm{N}$ ratio of 8.5. The BP2 (installed electric output of $280 \mathrm{kWh}$ ) was being fed with maize silage, cattle manure, grass silage and crop residues with a slurry $\mathrm{pH}$ value of 8 . The two mesophilic reactors have a total volume of $1,600 \mathrm{~m}^{3}$ operating at a total hydraulic residence time of 120 days with a rather low organic loading rate of $0.98 \mathrm{~kg} \mathrm{VS} \mathrm{m}^{-3} \mathrm{day}^{-1}$.

The analyzed reactor of BP1 was sampled several times during the period from December 2008 to May 2011. The other biogas reactor (BP2) was sampled in August 2013. Prior the sampling, reactors were stirred for $10 \mathrm{~min}$. From $10 \mathrm{~L}$ of the collected slurry, four sub-samples, a total of $20 \mathrm{~mL}$, were mixed with $20 \mathrm{~mL}$ of $99.8 \%$ ethanol and stored at $-20^{\circ} \mathrm{C}$ for genomic DNA extraction.

For verification of cell density by fluorescence microscopy, two extra samples were drawn from the reactor of BP1 in March and May 2010. The reactor content was fixed according to the protocol of [20] using either a fixative solution (4\% paraformaldehyde, PFA) or $99.8 \%$ ethanol and incubated for $4 \mathrm{~h}$ on ice. Afterwards, the cells were spun down by centrifugation $\left(5,000 \times g, 3 \mathrm{~min}, 4^{\circ} \mathrm{C}\right)$ and washed three times with phosphate-buffered saline (PBS) buffer. Finally, all cell pellets were suspended in one volume $1 \times$ PBS buffer and one volume $99.8 \%$ ethanol and stored at $-20^{\circ} \mathrm{C}$.

Further investigations on fungal presence were done in anaerobic laboratory reactors of $10-\mathrm{L}$ volume. In these experiments, polypropylene discs were exposed for variable time span and recovered, and the abundance of the present organism was assessed by different techniques. These experiments used similar substrates as described above as well as slaughter house waste material with an inoculum from the biogas plant described above. More details on the digestion experiments are given in [21].

\section{Fluorescence microscopy}

To determine the number of cells, diluted (100- to 200fold) cell suspension and $100 \mathrm{mg}$ of sterile glass beads (diameter $0.1 \mathrm{~mm}$ ) were filled in a $2-\mathrm{mL}$ microtube (Sarstedt, Nümbrecht, Germany) and homogenized using the RiboLyser (Hybaid Ltd., Middlesex, UK) at $4 \mathrm{~m} \mathrm{~s}^{-1}$ for $20 \mathrm{~s}$. The homogeneous cell suspension $(15 \mu \mathrm{L})$ was dropped onto each well of a Teflon-coated slide (eight wells, diameter $6 \mathrm{~mm}$, Menzel GmbH \& Co KG, Karlsruhe, Germany) and incubated for $15 \mathrm{~min}$ at $60^{\circ} \mathrm{C}$. Cells per well were stained with $20 \mu \mathrm{L}$ of a $10,000-$ fold diluted SYBR ${ }^{\oplus}$ Gold solution (Molecular Probes Inc., 
Eugene, OR, USA) per well for $10 \mathrm{~min}$ at room temperature, flushed with cold $\mathrm{ddH}_{2} \mathrm{O}$ and immediately dried with compressed air. An analogous procedure was done with 4',6'-diamidino-2-phenylindole (DAPI; $2.5 \mathrm{mg} \mathrm{mL}^{-1}$ ) instead of SYBR ${ }^{\odot}$ Gold. Fluorescence was detected using a Leica microscope (Leica, Solms, Germany). The microscope suitable for epifluorescence microscopy (resolution $\times$ 1,000 ) was equipped with a $100-\mathrm{W}$ mercury high-pressure bulb (HBO $103 \mathrm{~W} / 2)$ and adequate filter cubes. Digital images were taken with an AxioCam MRc 5 (Carl Zeiss, Jena, Germany) and the software AxioVision Rel. 4.8. Ten microscopic pictures (randomly chosen, magnification of $\times 1,000)$ were made per well. The following formula was used to calculate the total cell counts $\left(\mathrm{TC}_{\mathrm{c}}\right)$ per millilitre of reactor content: $\mathrm{TC}_{\mathrm{c}}=A / A_{\mathrm{mi}} \times C_{\mathrm{n}} \times D_{\mathrm{f}} . A$ is the total area of a well $\left(28.27 \mathrm{~mm}^{2}\right), A_{\mathrm{mi}}$ is the area of the microscopic image $\left(0.015552 \mathrm{~mm}^{2}\right), C_{\mathrm{n}}$ is the average cell number per microscopic image and $D_{\mathrm{f}}$ is the dilution factor per millilitre of reactor content.

\section{Conventional scanning electron microscopy}

The conventional scanning electron microscope (CSEM) DSM 942 (Carl Zeiss AG, Germany) was used for highresolution visualization of the samples $(\times 5,000)$. Polypropylene (PP) discs with a diameter of $9 \mathrm{~mm}$ were used as biofilm carriers. Samples for CSEM were either fixed in paraformaldehyde solution $(4 \%, w / v)$ or ethanol. After fixation of biofilms attached to PP discs, samples were dehydrated for 1 day in $80 \%$ and 90\% ethanol and 100\% isopropyl alcohol, respectively. After dehydration, samples were critical point-dried (Polaron E 3000, Polaron Equipment Limited, Watford, England) and gold-coated. Structures were visualized by CSEM DSM 942 in high vacuum mode. The resolution under this mode reaches up to $4 \mathrm{~nm}$ at $30 \mathrm{kV}$. Signalling electrons were detected by a secondary electron detector and visualized on monitor. The optimal quality of micrographs was reached at a high voltage of 5 to $10 \mathrm{kV}$, a pressure of $2 \times 10^{-7} \mathrm{hPa}$, a working distance of 7 to $12 \mathrm{~mm}$ and a spot size of 9 .

\section{DNA isolation and purification}

Genomic DNA was isolated from the initial treatment of $2 \mathrm{~mL}$ of fixed reactor content according to [7]. Afterwards, the genomic DNA was extracted following the protocol of the 'High Pure PCR Template Preparation Kit' from Roche (Mannheim, Germany). For further purification of genomic DNA, the RNA was removed by RNase digestion $\left(20 \mathrm{ng} \mathrm{mL}{ }^{-1}\right)$ for $20 \mathrm{~min}$ at $37^{\circ} \mathrm{C}$, followed by a standard phenol chloroform extraction and ethanol precipitation. Yields of the genomic DNA extracted were determined photometrically with the Ultraspec 3100 pro (GE Healthcare Bioscience AB, Uppsala, Sweden). The eukaryotic (fungal) members were characterized by creating clone libraries based on 18S rRNA gene and internal transcribed spacer 1 (ITS1) fragments of eukaryotes. Colony polymerase chain reaction (PCR) was performed using a thermocycler (MWG-Biotech AG, Ebersberg, Germany). All employed primers were synthesized by biomers.net GmbH (Ulm, Germany). Eukaryotic 18S rRNA gene was amplified using the primer set Euk1a and Euk516r-GC [22] with the DF Taq DNA polymerase (Genaxxon bioscience $\mathrm{GmbH}$ ). 18S rRNA gene fragments of approximately 500 bp were generated with the following protocol: initial denaturation at $95^{\circ} \mathrm{C}$ for $5 \mathrm{~min} ; 8 \mathrm{cycles}$ of $94^{\circ} \mathrm{C}$ for $30 \mathrm{~s}, 55^{\circ} \mathrm{C}$ for $30 \mathrm{~s}$ and $72^{\circ} \mathrm{C}$ for $1 \mathrm{~min} ; 20$ cycles of $92^{\circ} \mathrm{C}$ for $30 \mathrm{~s}, 52^{\circ} \mathrm{C}$ for $30 \mathrm{~s}$ and $72^{\circ} \mathrm{C}$ for $1 \mathrm{~min}$; followed by final extension at $72^{\circ} \mathrm{C}$ for $10 \mathrm{~min}$. The amplification of the fungal ITS1 region was performed using the primer set ITS1-F [23] and Neo-qPCR Rev [24]. ITS1 fragments of approximately 400 bp were amplified using Phusion High-Fidelity DNA polymerase (Thermo Fisher Scientific Inc.) by the following protocol (modified from Fliegerová et al. [25]): initial denaturation at $98^{\circ} \mathrm{C}$ for $30 \mathrm{~s} ; 10$ cycles of $98^{\circ} \mathrm{C}$ for $10 \mathrm{~s}, 62.5^{\circ} \mathrm{C}$ for $45 \mathrm{~s}$ and $72^{\circ} \mathrm{C}$ for $15 \mathrm{~s} ; 30$ cycles of $98^{\circ} \mathrm{C}$ for $10 \mathrm{~s}, 67.5^{\circ} \mathrm{C}$ for $45 \mathrm{~s}$ and $72^{\circ} \mathrm{C}$ for $15 \mathrm{~s}$; followed by final extension at $72^{\circ} \mathrm{C}$ for $10 \mathrm{~min}$.

\section{Cloning and sequencing}

Amplified 18S rRNA gene and ITS1 fragments were cloned into either the pDrive Cloning Vector (QIAGEN GmbH, Hilden, Germany) or pJET1.2/blunt Cloning Vector also according to the instructions provided by the manufacturer. Cold competent Escherichia coli DH5 $\alpha$ cells were used for heat shock transformation of plasmid DNA [26]. Colony PCR was carried out in order to recover the cloned DNA fragment from the recombinant plasmid, either of the $18 \mathrm{~S}$ rRNA gene or the ITS1 fragments, respectively. Restriction fragment length polymorphism (RFLP) analysis was performed for $18 \mathrm{~S}$ rRNA gene PCR fragments. Fragments of the expected size were combined with an appropriate restriction enzyme mix and the appropriate enzyme buffer. Electrophoresis to separate restriction fragments was done using $2 \%$ agarose gels in a TAE buffer system (20 mM Tris, $10 \mathrm{mM}$ acetic acid and $0.5 \mathrm{mM}$ EDTA; pH 8 ) at $80 \mathrm{~V}$. The resulting RFLP banding patterns were compared visually. In case of identical RFLP banding patterns, one representative DNA fragment was chosen for DNA sequencing (Eurofins MWG Operon, Ebersberg, Germany). The resulting representative DNA sequences and the corresponding RFLP banding patterns, respectively, were defined as an operational taxonomic unit (OTU). In case of ITS1 PCR fragments, all amplified fragments were sequenced, and therefore, no OTU had to be defined.

The reference sequences used to analyze the $18 \mathrm{~S}$ rRNA gene and ITS1 region sequences were retrieved from GenBank (National Center for Biotechnology Information database) and were analyzed using BLASTn [27]. 
All obtained nucleotide sequences were checked for chimeric artefacts with the Mallard software tool (version 1.02) [28]. All nucleotide sequences obtained in this study were deposited in the NCBI GenBank database. The fungal 18S rRNA gene sequences and ITS1 region sequences are available under the accession numbers JF421674 to JF421678, JF421681 and KF977129 to KF977143, respectively.

\section{Results and discussion}

\section{Microscopical analysis}

In total, 87 evaluated fluorescent micrographs gave on average $1.44( \pm 0.3) \times 10^{10}$ prokaryotic cells $\mathrm{mL}^{-1}$ reactor content of BP1. Autofluorescent methanogenic cells (coenzyme $\mathrm{F}_{420}$ ) were counted on 75 micrographs providing an average abundance of $3.5( \pm 0.78) \times 10^{8}$ archaea $\mathrm{mL}^{-1}$ reactor content. This indicates that archaea accounts for $2.3 \%$ of the total prokaryotic cells (see [19] for more details). DAPI-stained fungal cells (Figure 1) were assessed on a total of 26 micrographs and were in the same order of magnitude $\left(2.03( \pm 1.05) \times 10^{8}\right.$ cells per $\left.\mathrm{mL}\right)$ as the methanogens. Eukaryotic fungal cells were distinguished by an intensive fluorescence and had a mean circumference of $7.7( \pm 1.8) \mu \mathrm{m}$ and an expanse of $2.8( \pm 1.0) \mu \mathrm{m}^{2}$, thus significantly larger than prokaryotic bacterial and archaeal cells. CSEM micrographs confirmed the size of prokaryotic organisms. Precise measurement of unstained fungal cells (about $10 \mu \mathrm{m}$ in diameter) could be achieved by up to five times higher resolution compared to epifluorescence microscopy.

CSEM micrographs (Figure 2A,B) show fungal cells where almost all other cells were removed due to PFA fixation. The size difference between the eukaryotic fungal cells and the prokaryotic microorganisms is visible on images in Figure 2A,C. Fungi are 1 order of magnitude larger as can be seen from the large fungal bodies surrounded by prokaryotes. Micrographs in Figure 2C,D display fungal cells embedded in a prokaryotic biofilm layer, which was preserved by ethanol fixation. Such spatial arrangement with prokaryotes and fungi embedded in the common matrix of extracellular polysaccharides (EPS) guarantee fast transfer of metabolites such as acetate and hydrogen towards the methanogens.

The evidence of facultative anaerobic fungi in the studied biogas reactor of BP1 was based on their intensive fluorescence and the cell size and was demonstrated further by the presence of fungal $18 \mathrm{~S}$ rRNA gene sequences. The genome of eukaryotic fungal cells is much larger than that of the prokaryotic ones. Thus, fungal cells contain higher amounts of DNA resulting in high fluorescence (Figure 1). Already in Figure 1, the several times larger circumference and expanse of presumably eukaryotic fungal cells are obvious compared to other prokaryotic cells stained by DAPI. The fungal cells found (Figure 2) with the diameter of $10 \mu \mathrm{m}$ are comparable to other anaerobic fungi of the genus Saccharomyces [29] and others described in a review by Ho et al. [30].

\section{Molecular and phylogenetic analysis}

Clones were randomly chosen from several hundred colonies obtained after transformation. Six clones from BP1 contained eukaryotic $18 \mathrm{~S}$ rRNA gene sequences, and further 15 ITS1 region sequences were determined in samples from the BP2 (Table 1). These fungal $18 \mathrm{~S}$ rRNA gene sequences were classified into the subphyla Agaricomycotina, Mucoromycotina, Pucciniomycotina and Saccharomycotina. The fungal ITS1 region sequences were identified as belonging to the fungal subphyla Agaricomycotina and Pezizomycotina and to the class Neocallimastigomycetes. Sequences from uncultured fungal clones were assigned to the phylogenetically closest species within the respective subphylum using one of the top five BLAST hits. The exact determination of the uncultured Pucciniomycotina clone (Euk 12 pD), uncultured soil fungus clone (K73) and

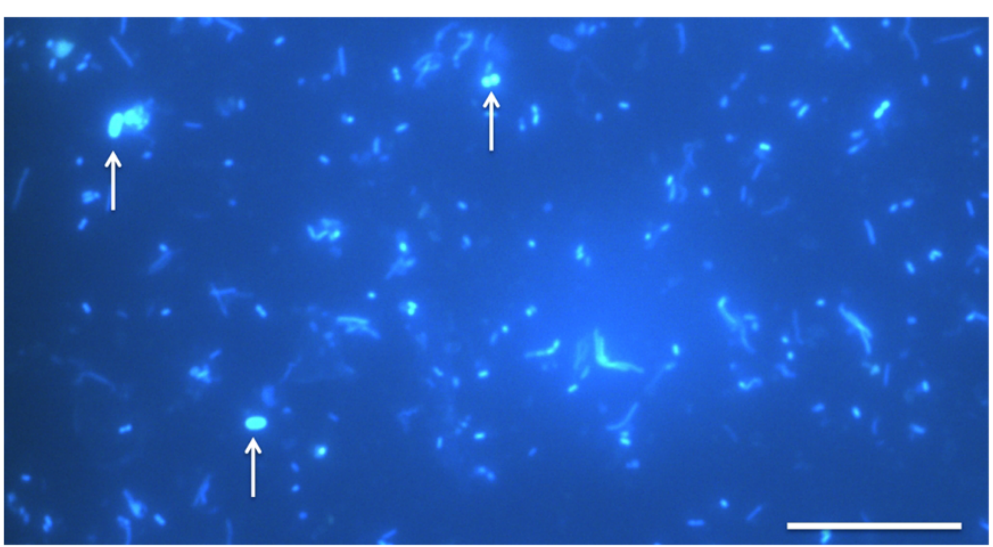

Figure 1 Epifluorescence micrograph showing cells in the biogas reactor content. Cells were stained with DAPI. Cells marked by arrows are presumably of fungal origin (scale bar $20 \mu \mathrm{m}$ ). 

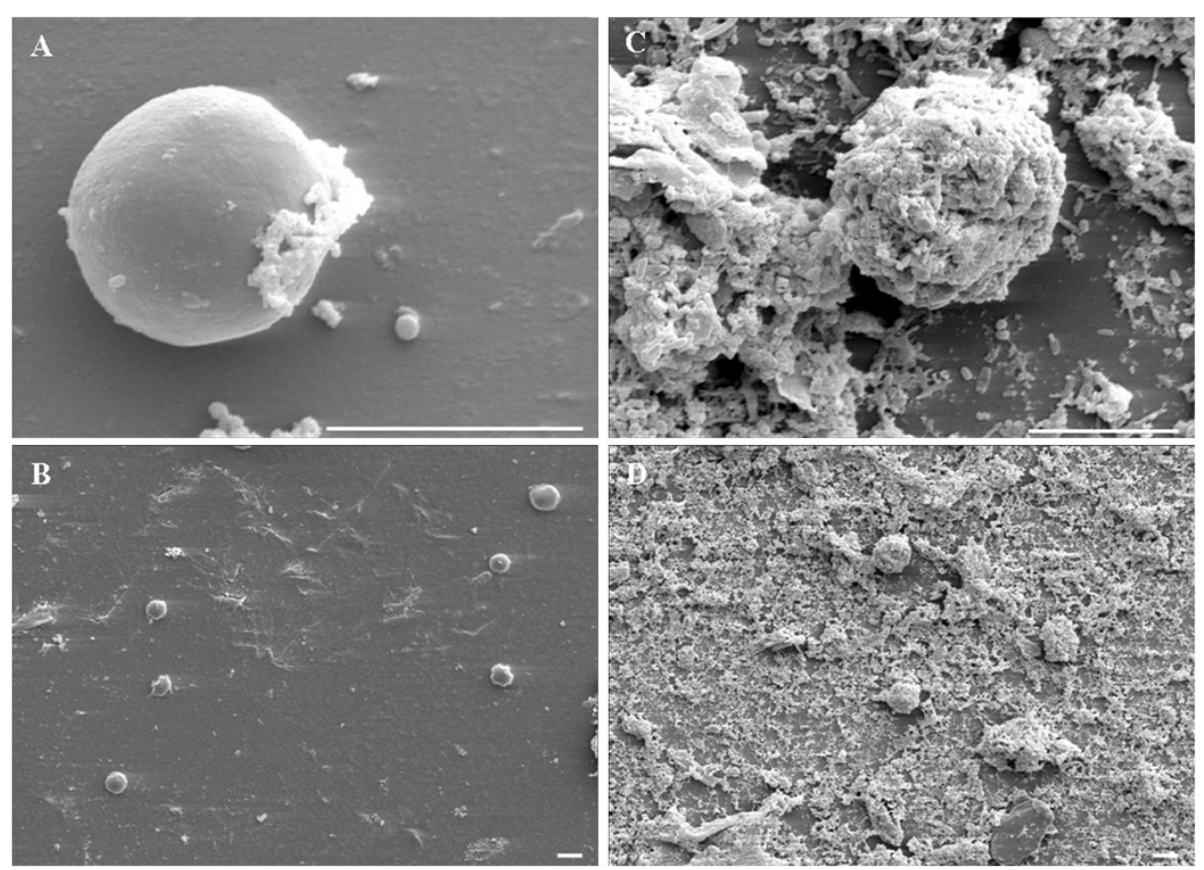

Figure 2 CSEM micrographs of fungal cells on biofilm carriers (polypropylene discs). (A, B) Sole fungal cells. (C, D) Fungal cells embedded in a prokaryotic biofilm layer (scale bar $10 \mu \mathrm{m}$ ).

uncultured Neocallimastigales clones (K76, K81) could not be assigned on the species level. However, at decreasing precision, 18S rRNA gene and 15 ITS1 region clone sequences gave the following identification: clone Euk $12 \mathrm{pD}$ Malassezia pachydermatis isolate AFTOL-ID 856, identity 96\%; clone K76 Anaeromyces sp. FFEX4, identity 85\%; clone K81 no cultivated species matching; clone K73 Pezizales sp. G-P4, identity $90 \%$.

The identified four subphyla (based on 18S rRNA gene sequences) of facultative anaerobic fungi, the Agaricomycotina, Mucoromycotina, Pucciniomycotina and Saccharomycotina, as well as the identified species from the genera Mucor and Saccharomyces (Table 1) were shown to be consistently present within the highly diverse reactor community of BP1 over the period of more than 1 year [19]. Addressing the ITS1 region sequences obtained from BP2 gave new evidence concerning the presence of the strongly anaerobic fungal class Neocallimastigomycetes. Both molecular approaches enlarged significantly our insight into the fungal diversity of biogas reactors. Our current knowledge about the role of fungi in biogas reactors is, however, still low. Fungi were not found in previous microscopic surveys $[7,14,31,32]$, which only focused on the bacterial and archaeal communities. However, rumen liquor as well as faeces from ruminants and non-ruminants contains fungi belonging to Anaeromyces, Orpinomyces, Caecomyces, Piromyces and Neocallimastix $[9,10]$. Therefore, it can be assumed that most of biogas reactors supplied with liquid or solid manure are inhabited by facultative or even obligatory anaerobic fungi (Table 1).

\section{Role of fungi in biogas reactors}

The average abundance of $2.03( \pm 1.05) \times 10^{8}$ fungal cells per $\mathrm{mL}$ reactor content (BP1) is comparable to the relative presence of methanogenic archaea found in the same reactor [19]. A significantly larger size of fungal cells (Figures 1 and 2) suggests a high substrate requirement to maintain the metabolic activity of fungal cells. It must be highlighted that the same relative abundance of fungi as that of methanogens must have consequences for the anaerobic degradation process. Furthermore, the eukaryotic community dominated by fungi did not change, and the fungi remained present over the time period of 1 year [19]. Also, Ravella et al. [33] demonstrated that a laboratory biogas reactor is a suitable habitat for fungi, and the authors were able to isolate different viable fungal strains.

A review article [30] distinguished several fungi attached to fibrous plant material. After motile flagellated zoospores from the fluid become attached to the digestible materials, vegetative stages produce germ tubes that elongate very rapidly and build a network of rhizoids or hyphae in the plant tissues. Fungi from anaerobic environments (e.g. Piromyces, Neocallimastix [12], Orpinomyces, Anaeromyces [10]) are possessing fibrolytic activity and are able to enhance the digestibility of fibrous feeds as was documented for cattle [34], as well as wild-living 
Table 1 Clone sequences of fungal 18S rRNA gene and ITS1 region fragments from BP1 and BP2

\begin{tabular}{|c|c|c|c|c|c|}
\hline Phylum & Subphylum/class & Clone & Sequence related to & $\begin{array}{l}\text { Identity } \\
\text { (\% cpa) }\end{array}$ & $\begin{array}{c}\text { Accession } \\
\text { number }\end{array}$ \\
\hline \multicolumn{6}{|c|}{ Fungal 185 rRNA gene sequence } \\
\hline \multirow[t]{2}{*}{ Ascomycota } & Saccharomycotina & Euk 06 pD & Saccharomyces cerevisiae strain YJM789 & 99 & JQ277730 \\
\hline & & Euk 1-4 pJ & S. cerevisiae strain YJM789 & 99 & JQ277730 \\
\hline \multirow[t]{2}{*}{ Basidiomycota } & Pucciniomycotina & Euk $12 \mathrm{pD}$ & Uncultured Pucciniomycotina clone D0735_42_M & 99 & EU647044 \\
\hline & Agaricomycotina & Euk $21 \mathrm{pD}$ & Sclerotium sp. BSC-97 & 99 & AF010303 \\
\hline \multirow[t]{2}{*}{ Incertae sedis } & Mucoromycotina & Euk 2-8 pJ & Mucor circinelloides f. circinelloides strain WA0000017591 & 99 & HM641689 \\
\hline & & Euk 57 pD & Rhizomucor endophyticus strain CBS 385.95 & 99 & HM623313 \\
\hline \multicolumn{6}{|c|}{ Fungal ITS1 region sequence } \\
\hline \multirow[t]{6}{*}{ Ascomycota } & Pezizomycotina & K01 & Hypocreales sp. Vega851 & 96 & EF694655 \\
\hline & & K27 & Hypocrea sp. KBS0814F & 98 & JQ437611 \\
\hline & & K38 & Cladosporium sp. AF13 & 99 & JX173100 \\
\hline & & K39 & Aspergillus fumigatus strain ATCC 1022 & 99 & HQ026746 \\
\hline & & K58 & Pleosporales sp. 5 TMS-2011 & 89 & HQ631052 \\
\hline & & K91 & Cladosporium sp. F0910-49U4 & 99 & HG008746 \\
\hline \multirow[t]{6}{*}{ Basidiomycota } & Agaricomycotina & K21 & Basidiomycota sp. 54 OA-2013 & 95 & JX507646 \\
\hline & & K24 & Wallemia sp. F53 & 97 & FJ755832 \\
\hline & & K31 & Mrakia sp. CBS 8907 & 99 & AY038836 \\
\hline & & K79 & Guehomyces pullulans isolate ANT03-093 & 99 & $J X 171177$ \\
\hline & & K87 & Mrakia sp. CBS 8907 & 99 & AY038836 \\
\hline & & K83 & Mrakia sp. CBS 8907 & 99 & AY038836 \\
\hline \multirow[t]{2}{*}{ Neocallimastigomycota } & Neocallimastigomycetes (class) & K76 & Uncultured Neocallimastigales clone 238518 & 98 & KC431216 \\
\hline & & K81 & Uncultured Neocallimastigales clone 8SC4cg07 & 90 & GU909951 \\
\hline Unclassified & Unclassified & K73 & Uncultured soil fungus clone C152 & 97 & JX489840 \\
\hline
\end{tabular}

Corresponding sequences were retrieved from the NCBI database by the nucleotide BLAST algorithm. Accession numbers: fungal ITS1 region sequences, KF977129-KF977143; fungal 18S rRNA gene sequences, JF421674-JF421678, JF421681s.

herbivores like buffalo [35] and elephants [9]. Celluloses and hemicelluloses are forming plant cell walls, and their penetration and disintegration are the limiting steps in the anaerobic digestion of fibrous material, especially if they are embedded within the lignocellulose complex [36]. The beneficial role of fungi in the anaerobe biogas process is based on their ability to adhere on plant surfaces and to penetrate the cell walls. Through this, they open the cells for numerous members of the bacterial community and speed up the whole decomposition process.

The genus Mucor, which was found in the present study, has members present worldwide in soil and environmental samples [37]. They are characterized by high protease activity [38] that could improve the digestion of organic residues in a biogas plant. The also identified subphlyum Pucciniomycotina includes more than 8,000 described species, which are known as saprophytes and parasites of plants, animals and other fungi. Therefore, they are able to disintegrate organic materials. More specific estimates on their role in the biogas reactor (BP1) were not possible however. Although the applied detection methods in the current study could not provide any information regarding fungal enzymatic activity, there is increasing evidence supporting the importance of facultative anaerobic fungi in producing enzymes for degradation of fibre-rich substrates [9,12,34]. Enzyme essays showed especially high cellulase, carboxymethylcellulase, xylanase and avicelase activities $[9,10]$.

There are also positive effects of anaerobic fungi known mainly from animal breeding. Cultures of Saccharomyces cerevisiae and their extracts are in use as feed additive for cattle in ruminal fermentation for many years [17,39]. Lila et al. [40] showed that living cells of $S$. cerevisiae increased the numbers of total viable bacteria, especially cellulolytic ones in the cattle rumen. Newbold et al. [41] reported the same beneficial effect on the rumen of sheep. Thus, S. cerevisiae in biogas plants may have similar positive effects for the abundance of cellulolytic bacteria. Although the investigated biogas reactor of BP1 was not utilizing residues from cattle breeding but pig manure, the Saccharomyces were found as a sustaining member of the microbial community.

Still, further targeted investigations are needed on the presence and activity of fungi in order to relate them to 
the used substrates. It is necessary to test how strongly the fungal presence depends on the regular and repeated inoculation by animal manure [34]. As facultative anaerobic fungi [37] are widely distributed in the environment, biogas reactors fed by plant material may offer preferable living conditions, even without ruminant manure (c.f. BP1). The metabolic activity of fungi in the anaerobic process can be assessed by volatile fatty acid (VFA) concentration. In fungal isolates incubated on filter paper [9] or wheat straw [10], the VFA concentration increased significantly. Teunissen et al. [12] reported the highest production of acetate and formate, together with hydrogen, by the investigated strains of Neocallimastix and Piromyces. Furthermore, anaerobic fungi are building syntrophic interactions with archaea where the latter utilizes the fungiproduced hydrogen for methanogenesis [10], thus keeping the hydrogen partial pressure low - a prerequisite for a stable biogas process. Markedly, the larger fungal cells had a similar share (based on cell numbers) within the reactor community as the methanogenic archaea, all closely embedded in the EPS matrix (see Figure 2).

In summary, the presence of fungi in biogas reactors (Table 1) increases and possibly also speeds up the decomposition of substrates rich in lignocelluloses as reported for cattle [34] and can broaden the utilization of various substrates for biogas production. Therefore, it is necessary to consider further possible substrate applications and implications for sustainable biomass use.

\section{Implications for sustainable use of biogas substrates}

Human population exploits large quantities of biogenic resources. Based on FAO statistics for 1995, estimates showed that about $20 \%$ (11.5 Pg C) of the terrestrial net primary production (NPP) is acquired by humans, from which food accounts for 4.1 Pg C [42]. It is evident that the exploitation of NPP increased significantly since 1995 along with the amount of organic waste material. Many municipalities around the world are facing increasing problems in dealing with domestic organic waste and urban greening waste [43].

Figure 3 lists the most widespread treatments for biowaste, while the amount of lignocellulosis is one important criterion for the treatment. Generally, organic material must not end in landfills, especially due to uncontrolled long-lasting methane emissions and other environmental impacts, which are most prominent in fast-developing countries [44] and megacities [45]. Applying thermic conversion like incineration and pyrolysis, air pollution problems must be solved and initial investments are very high $[44,45]$. Moreover, large quantities of organic waste have high water content, often over $80 \%$, meaning that even additional energy might be needed when burning such material. One often neglected disadvantage of thermal treatment of organic material is that plant nutrients

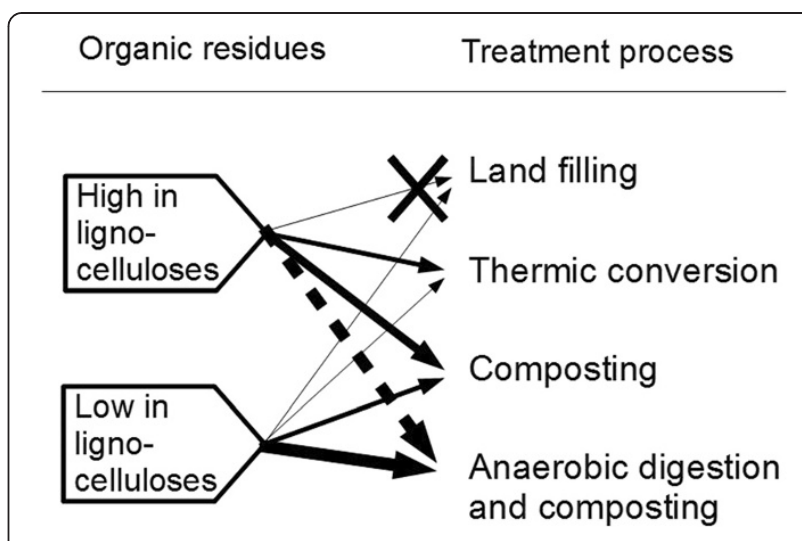

Figure $\mathbf{3}$ Treatment of organic residues. Line thickness indicates preferential pathway, dashed line under high metabolic activity of facultative anaerobic fungi.

from the waste are going to get lost. Burning of organic waste with an average nitrogen concentration about $15 \mathrm{mg} \mathrm{N} \mathrm{g}^{-1}$ waste [46] leads to nitrous gas emissions. Also, other valuable elements like phosphorus and potassium have to be replenished in agricultural soils as the ash and slag produced in incineration plants must be deposited in landfills.

Composting of organic material rich in lignocelluloses is the most applied treatment. It requires comparably low initial investment, and the operation of a composting plant is simpler than other technologies. However, composting itself is also an energy-demanding process. Depending on the technical operation, up to $100 \mathrm{kWh}$ $\mathrm{t}^{-1}$ fresh material is needed for handling and aeration [4]. During the self-heating of the compost heap, high $\mathrm{CO}_{2}$ emissions due to oxidation of easily degradable compounds are additionally emitted. Further major shortcomings of composting - at least for nutrient-rich agricultural waste - are nutrient losses, leading to reduced fertilizer value, and possibly point-source pollution [47] such as methane and leachate [48].

Dry digestion can be considered as an appropriate treatment for the organic fraction of MSW and fibre-rich material owing several advantages for these heterogeneous substrates of TS over $30 \%[44,46]$. Compared to the mesophilic process, thermophilic dry fermentation proved to lead to higher methane yields and VS degradation when applied to cow dung [49] and to fibre-rich green yard waste (M Zak, personal communication). In fact, cellulase and xylanase activities in anaerobic fungal cultures had their optima at $50^{\circ} \mathrm{C}$ [12], which supports the importance of fungi in the anaerobic degradation of material rich in lignocelluloses.

\section{Conclusions}

For the aforementioned reasons, anaerobic digestion is the most appropriate treatment of organic waste in order to 
achieve waste stabilization and energy generation [44,50,51]. Therefore, anaerobic treatment can produce a high amount of renewable energy, and subsequent composting will retain plant nutrients in the substrate for further use as organic fertilizer. However, appropriate biogas technology for fibre-rich substrates like straw, material from landscaping, urban greening, etc. is needed [46]. The thermophilic process might be appropriate $[12,49]$ to generate higher methane yields. At this point, fungi play a key role in opening up the less accessible lignocellulosic biomass and in increasing the biogas gain from anaerobic digestion.

\section{Competing interests}

The authors declare that they have no competing interests.

\section{Authors' contributions}

MK made an interpretation of the findings towards sustainable use of waste biomass and drafted the manuscript. SL made the microscopic analysis and interpretation of the micrographs. FRB collected the samples for molecular analyses, performed the related evaluation and, together with $\mathrm{SL}$, contributed to the manuscript draft. All authors read and approved the final manuscript.

\section{Authors' information}

MK is working in ecology and environmental sciences at the Ulm University since 1995. His research group is focussed on biogas production from waste material. He is also involved in regional sustainable development. SL is a PhD candidate currently working on cellulolytic bacteria and anaerobic fungi. FRB has a postdoctoral position at the Institute of Mirobiology and Biotechnology and is involved in several projects dealing with anaerobic metabolism.

\section{Acknowledgements}

This study was funded by the Baden-Württemberg Stiftung, Biomass to Energy Programme (Project No. Bio 06). We are very grateful to Prof. P. Dürre at the UIm University for providing laboratory space for microbial analysis.

\section{Author details}

${ }^{1}$ Institute of Systematic Botany and Ecology, Ulm University, Albert-Einstein-Allee 11, Ulm 89081, Germany. ${ }^{2}$ Institute of Microbiology and Biotechnology, UIm University, Albert-Einstein-Allee 11, Ulm 89081, Germany.

\section{Received: 23 July 2013 Accepted: 4 February 2014}

Published: 13 March 2014

\section{References}

1. Weiland P (2010) Biogas production: current state and perspectives. Appl Microbiol Biotechnol 85:849-860

2. Adhikari BK, Trémier A, Martinez J, Barrington S (2010) Home and community composting for on-site treatment of urban organic waste: perspective for Europe and Canada. Waste Manag Res 28:1039-1053. doi:10.1177/0734242X10373801

3. Wiesenthal T, Mourelatou A, Petersen J, Taylor P (2006) How much bioenergy can Europe produce without harming the environment? European Environ Agency 7:1-70

4. Kern M, Raussen T, Funda K, Lootsma AHH (2010) Aufwand und Nutzen einer optimierten Bioabfallverwertung hinsichtlich Energieeffizienz, Klima- und Ressourcenschutz. Umweltbundesam Texte 43/2010, p 196

5. Schink B (1997) Energetics of syntrophic cooperation in methanogenic degradation. Microbiol Mol Biol Rev 61:262-280

6. Ahring BK (2003) Perspectives for anaerobic digestion. Adv Biochem Eng Biotechnol 81:1-30

7. Nettmann E, Bergmann I, Pramschufer S, Mundt K, Plogsties V, Herrmann C, Klocke M (2010) Polyphasic analyses of methanogenic archaea communities in agricultural biogas plants. Appl Environ Microbiol 76:2540-2548
8. Williams AG, Coleman GS (1997) The rumen protozoa. In: Hobson PN, Stewart CS (eds) The rumen microbial ecosystem. Chapman and Hall, New York, pp 73-139

9. Nagpal R, Puniya A, Sehgal J, Singh K (2011) In vitro fibrolytic potential of anaerobic rumen fungi from ruminants and non-ruminant herbivores. Mycoscience 52:31-38. doi:10.1007/s10267-010-0071-6

10. Sirohi SK, Choudhury PK, Dagar SS, Puniya AK, Singh D (2012) Isolation, characterization and fibre degradation potential of anaerobic rumen fungi from cattle. Ann Microbiol 63:1187-1194. doi:10.1007/s13213-012-0577-6

11. Ushida K (2011) Symbiotic methanogens and rumen ciliates. In: Hackstein JHP (ed) (Endo)symbiotic methanogenic archaea, vol. 19. Springer, Berlin, pp 25-34

12. Teunissen MJ, Smits AA, Op den Camp HJ, Huis in't Veld JHJ, Vogels GD (1991) Fermentation of cellulose and production of cellulolytic and xylanolytic enzymes by anaerobic fungi from ruminant and non-ruminant herbivores. Arch Microbiol 156:290-296

13. Orpin CG, Joblin KN (1997) The rumen anaerobic fungi. In: Hobson PN Stewart CS (eds) The rumen microbial ecosystem. Chapman and Hall, New York, pp 145-184

14. Krakat N, Schmidt S, Scherer P (2010) The mesophilic fermentation of renewable biomass: does hydraulic retention time regulate diversity of methanogens? Appl Environ Microbiol 76:6322-6326

15. Wubah DA, Akin DE, Bomeman WS (1993) Biology, fiber-degradation, and enzymology of anaerobic zoosporic fungi. Crit Rev Microbiol 2:99-115

16. Krause DO, Denman SE, Mackie Rl, Morrison M, Rae AL, Attwood GT, McSweeney CS (2003) Opportunities to improve fiber degradation in the rumen: microbiology, ecology, and genomics. FEMS Microbiol Rev 27:663-693

17. Tripathi VK, Sehgal JP, Puniya AK, Singh K (2007) Hydrolytic activities of anaerobic fungi from wild blue bull (Boselaphus tragocamelus). Anaerobe 13:36-39

18. Akin DE, Borneman WS (1990) Role of rumen fungi in fiber degradation. J Dairy Sci 73:3023-3032

19. Bengelsdorf FR, Gerischer U, Langer S, Zak M, Kazda M (2013) Stability of a biogas-producing bacterial, archaeal and fungal community degrading food residues. FEMS Microbiol Ecol 84:201-212. doi:10.1111/1574-6941.12055

20. Daims H, Stoecker K, Wagner M (2005) Fluorescence in situ hybridization for the detection of prokaryotes. In: Osborn AM, Smith CJ (eds) Advanced methods in molecular microbial ecology. Bios-Garland, Abingdon, pp 213-239

21. Langer S, Schropp D, Bengelsdorf F, Othman M, Kazda M (2013) Dynamics of biofilm formation during anaerobic digestion of organic waste. Anaerobe, in press

22. Scanlan PD, Marchesi JR (2008) Micro-eukaryotic diversity of the human distal gut microbiota: qualitative assessment using culture-dependent and -independent analysis of faeces. ISME J 2:1183-1193

23. Gardes M, Bruns TD (1993) ITS primers with enhanced specificity for basidiomycetes - application to the identification of mycorrhizas and rusts. Mol Ecol 2:113-118

24. Edwards JE, Huws SA, Kim EJ, Kingston-Smith AH, Jimenes HR, Skot KP Griffith GW, McEwan NR, Theodorou MK (2008) Dynamics of initial colonization of nonconserved perennial ryegrass by anaerobic fungi in the bovine rumen. FEMS Microbiol Ecol 66:537-545

25. Fliegerová K, Mrázek J, Hoffmann K, Zábranská J, Voigt K (2010) Diversity of anaerobic fungi within cow manure determined by ITS1 Analysis. Folia Microbiol 55:319-325

26. Inoue $\mathrm{H}$, Nojima H, Okayama H (1990) High efficiency transformation of Escherichia coli with plasmids. Gene 96:23-28

27. Altschul SF, Gish W, Miller W, Myers EW, Lipman DJ (1990) Basic local alignment search tool. J Mol Biol 215:403-410

28. Ashelford KE, Chuzhanova NA, Fry JC, Jones AJ, Weightman AJ (2006) New screening software shows that most recent large 16S rRNA gene clone libraries contain chimeras. Appl Environ Microbiol 72:5734-5741

29. Barnett JA (1992) The taxonomy of the genus Saccharomyces Meyen ex Reess: a short review for non-taxonomists. Yeast 8:1-23

30. Ho Y, Abdullah N, Jalaludin S (2000) The diversity and taxonomy of anaerobic gut fungi. Fungal Divers 4:37-51

31. Schnürer A, Zellner G, Svensson BH (1999) Mesophilic syntrophic acetate oxidation during methane formation in biogas reactor. FEMS Microbiol Ecol 29:249-261

32. Schlüter A, Bekel T, Diaz NN, Dondrup M, Eichenlaub R, Gartemann KH, Krahn I, Krause L, Krömeke H, Kruse O, Mussgnug JH, Neuweger H, Niehaus 
K, Pühler A, Runte KJ, Szczepanowski R, Tauch A, Tilker A, Viehöver P, Goesmann A (2008) The metagenome of a biogas-producing microbial community of a production-scale biogas plant fermenter analysed by the 454-pyrosequencing technology. J Biotechnol 136:77-90

33. Ravella SR, James S, Bond CJ, Roberts IN, Cross K, Retter A, Hobbs PJ (2010) Cryptococcus shivajii sp. nov.: a novel basidiomycetous yeast isolated from biogas reactor. Curr Microbiol 60:12-16, doi:10.1007/s00284-009-9493-9

34. Sirohi SK, Choudhury, Dagar SS,PK, Puniya AK, Singh D (2013) Ribosomal ITS1 sequence-based diversity analysis of anaerobic rumen fungi in cattle fed on high fiber diet. Ann Microbiol 63:1571-1577. doi:10.1007/s13213-013-0620-2

35. Paul SS, Deb SM, Punia BS, Singh D, Kumar R (2010) Fibrolytic potential of anaerobic fungi (Piromyces sp.) isolated from wild cattle and blue bulls in pure culture and effect of their addition on in vitro fermentation of wheat straw and methane emission by rumen fluid of buffaloes. J Sci Food Agric 90:1218-1226. doi:10.1002/jsfa.3952

36. Lübken M, Gehring T, Wichern M (2010) Microbiological fermentation of lignocellulosic biomass: current state and prospects of mathematical modeling. Appl Microbiol Biotechnol 85:1643-1652. doi:10.1007/s00253-009-2365-1

37. Ribes JA, Vanover-Sams CL, Baker DJ (2000) Zygomycetes in human disease. Clin Microbiol Rev 13:236-301

38. Alves MH, de Campos-Takaki GM, Okada K, Pessoa IHF, Milanez Al (2005) Detection of extracellular protease in Mucor species. Rev Iberoam Micol 22:114-117

39. Wallace RJ (1994) Ruminal microbiology, biotechnology, and ruminant nutrition: progress and problems. J Anim Sci 72:2992-3003

40. Lila ZA, Mohammed N, Yasui T, Kurokawa Y, Kanda S, Itabashi H (2004) Effects of a twin strain of Saccharomyces cerevisiae live cells on mixed ruminal microorganism fermentation in vitro. J Anim Sci 82:1847-1854

41. Newbold CJ, Wallace RJ, Chen XB, Mclntosh FM (1995) Different strains of Saccharomyces cerevisiae differ in their effects on ruminal bacterial numbers in vitro and in sheep. J Anim Sci 73:1811-1818

42. Imhoff M, Bounoua L, Ricketts T, Loucks C (2004) Global patterns in human consumption of net primary production. Nature 429:870-873. doi:10.1038/ nature02685

43. Zhao MX, Yan Q, Ruan WQ, Miao HF, Ren HY, Xu Y (2011) Enhancement of substrate solubilization and hydrogen production from kitchen wastes by pH pretreatment. Environ Technol 32:119-125. doi:10.1080/ 09593330.2010.482596

44. Jha A, Li J, Nies L, Zhang L (2011) Research advances in dry anaerobic digestion process of solid organic wastes. Afr J Biotechnol 10:14242-14253. doi:10.5897/AJB11.1277

45. González Martínez T, Bräutigam K-R, Seifert H (2012) The potential of a sustainable municipal waste management system for Santiago de Chile, including energy production from waste. Energy Sustain Soc 2:24. doi:10.1186/2192-0567-2-24

46. Kazda M, Zak M, Kern M, Bengelsdorf F (2013) Treatment of liquid and solid municipal waste in anaerobic digestion optimized for biogas production. Fresenius Environ Bull 22:2048-2052

47. Möller K, Schulz R, Müller T (2010) Substrate inputs, nutrient flows and nitrogen loss of two centralized biogas plants in southern Germany. Nutr Cycl Agroecosyst 87:307-325. doi:10.1007/s10705-009-9340-1

48. Walker L, Charles W, Cord-Ruwisch R (2009) Comparison of static, in-vessel composting of MSW with thermophilic anaerobic digestion and combinations of the two processes. Bioresour Technol 100:3799-3807. doi:10.1016/j. biortech.2009.02.015

49. Jha A, Li J, Zhang L, Ban Q, Jin Y (2013) Comparison between wet and dry anaerobic digestions of cow dung under mesophilic and thermophilic conditions. Adv Water Resour 1:28-37

50. Elango D, Pulikesi M, Baskaralingam P, Ramamurthi V, Sivanesan S (2007) Production of biogas from municipal solid waste with domestic sewage. J Hazard Mater 141:301-304. doi:10.1016/j.jhazmat.2006.07.003

51. Khalid A, Arshad M, Anjum M, Mahmood T, Dawson L (2011) The anaerobic digestion of solid organic waste. Waste Manag 31:1737-1744. doi:10.1016/j. wasman.2011.03.021

doi:10.1186/2192-0567-4-6

Cite this article as: Kazda et al.: Fungi open new possibilities for anaerobic fermentation of organic residues. Energy, Sustainability and Society 2014 4:6.

Submit your manuscript to a SpringerOpen ${ }^{\circ}$ journal and benefit from:

- Convenient online submission

- Rigorous peer review

- Immediate publication on acceptance

- Open access: articles freely available online

- High visibility within the field

- Retaining the copyright to your article

Submit your next manuscript at $\gg$ springeropen.com 